\title{
Review
}

\section{The end of representative politics}

\author{
Simon Tormey \\ Polity Press, Cambridge, UK, 2015, vii+167 pp., ISBN-13: 978-0745681955
}

Contemporary Political Theory (2016) 15, e26-e28. doi:10.1057/cpt.2015.37;

published online 30 June 2015

The End of Representative Politics explores the critical juncture of the current crisis in representation, not to signify the redundancy of representation, but to problematise its status as the sine qua non of politics itself. Simon Tormey's challenging book seeks to displace conventional narratives about the terminal decline of democracy by uncovering an emerging set of new forms of politics. He traces the rise of a series of immediate or non-mediated modes of politics within the contemporary political landscape such as direct action, flash protests, boycotting and occupying. His provocative thesis is that rather than living in 'post-democratic' or 'post-political' times, perhaps we are witnessing the rebirth of democratic politics through these novel political practices that elude traditional representative forms. The book calls into question the assumption of Hannah Pitkin in her influential work, The Concept of Representation, that everyone wants to be governed by representatives. Tormey claims that while this may have been true in 1967 , it is increasingly contested today. Disillusioned with politicians and representative institutions, many new political movements have disavowed representative politics and positioned themselves in opposition to what they perceive to be stale and outdated institutions. However, there are paradoxes to these anti-representative movements as many of them go on to construct new forms of representation in protest figures such as Russell Brand, Slavoj Žižek and Bono, who make their own representative claims on behalf of disenfranchised communities. In the cases of Spain and Greece, such movements have also led to new political parties that have adopted older vertical organisational forms in order to challenge established parties and political elites. This book examines these tensions and assists us in understanding the nature of the growing concern with political representation today.

One of the strengths of the book is that it does not exclusively focus on the increasing technocratic nature of economic and political institutions, but highlights the growth of politics from a different perspective, a politics from below. The first chapter focuses on a new paradigm of activism, political mobilisation and other insurgent forms of politics, examining the Zapatistas, the World Social Forum and Occupy Wall Street. The falling legitimacy and credibility of older forms of

(C) 2016 Macmillan Publishers Ltd. 1470-8914 Contemporary Political Theory Vol. 15, 2, e26-e28 www.palgrave-journals.com/cpt/ 
mainstream politics as evinced by a decline in voter turnout, membership of political parties and trust in politicians provides the basis for an exploration of these new forms of 'politics at the margins'. Drawing on important studies from scholars such as Pippa Norris and Russell Dalton, the book contests the image of democracy as in uniform decline across the advanced industrialised nations. Various non-mainstream and non-electoral forms of political organising call into question the common myth of youth apathy and depoliticisation. However, it is at times unclear whether what Tormey is describing is a genuinely new phenomenon. While the impact of social media on politics has been transformational, there is a long history of similar social movements, boycotts, occupations, and rallies going back at least to the 1960s. Moreover, the Zapatistas and World Social Forum began in the 1990s and early 2000s, which, for a book that claims to analyse the present 'contours of a crisis' and an emerging politics 'after' representation, feels a little dated (p. 15).

The next chapter examines the origins of the concept of representation and traces its emergence as an important political idea and practice. This section constitutes a genealogy of the rise of representative politics through an analysis of Hobbes, Locke, the development of the nation-state and modern political identities, ideologies and interests. The intention of the author is to disentangle representative politics from other democratic practices in order to reveal the contingency and mutability of particular representative systems. In the following chapters, Tormey also locates a deeper shift of the decline of the 'representative paradigm' through an analysis of long-term structural changes that are altering the nature of modern societies. Attention is turned to forces of globalisation, transformations in information technology, the creation of new cultures and identities, the individualisation of contemporary politics and the decline of political hierarchy as a legitimate form of organisation. One of the main shifts that is treated at great length is the decline of political parties and the growth of non-hierarchical forms of organising through coalitions, alliances, affinity groups and networks. Tormey connects these dynamics with changes in our understanding of representation: 'Politics is undergoing a transformation in terms of citizens' ability and willingness to be represented by others, and particularly by "politicians", (p. 84). The broad disengagement from representative institutions has provided new avenues for political organisation and contestation.

One potential problem with the structure of the book lies in the dualism it establishes between direct and representative, immediate and mediated forms of politics. There are obvious issues with such a dichotomy as most so-called immediate forms of politics take place within a broader system of representative democracy. A number of these 'direct' forms of politics are directly connected to representative institutions such as petitioning government or protesting against an unpopular policy. While Tormey appears sensitive to the subtleties of this relationship, the main thrust of the book is framed within the overarching narrative of this binary. The claim that citizens are now more likely to do rather than to wait, or to act rather than be represented, obscures the complexity of how these forms of politics interact within 
intricate systems. A second tension in the book is the relationship between horizontal and vertical forms of politics. In one of the final chapters Tormey provides an interesting case study of the Spanish Indignados movement, which illustrates the conflicts between representative and more horizontal and participatory forms of politics. The relative ineffectiveness of Occupy and the $15 \mathrm{M}$ movement in Spain was a wakeup call for activists, which revealed the limits of social movements that do not directly contest state power. One of the lessons was that if the central structures of power are not challenged state institutions are able to resist the temporary pressure created by social mobilisation. As Tormey argues, '[m] any of those involved in the mobilizations therefore reached the conclusion that the only way of transforming the political dynamic was by challenging political elites directly via the electoral system' (p. 113). This raises the question of the extent to which we are witnessing a return to older vertical modes of politics or whether these parties have succeeded in creating new relationships between horizontal movements and vertical structures, and therefore new forms of negotiating the representation paradox.

What is the answer to the failure of representative institutions? One solution would be to reform the system of representation such that it provided more effective ways of representing citizens and their interests. Tormey suggests that we must go deeper still and 'rethink the basis of democratic life together', or how we could 'reconstruct political institutions along lines that permit a much greater input into the political process by ordinary people' (p. 4). It is clear that the book is inspired by a Rancièrian spirit of subversive and oppositional politics, and as such, the author refrains from offering ambitious blueprints for reform or prescriptive formulas of institutional transformation. Instead, the contours are traced of emerging practices that offer challenges to much contemporary thinking about representative politics. The result is an insightful and well-crafted book that invites further discussion on the future of democratic politics and its relationship to forms of representation.

James Muldoon

University of Warwick, Coventry CV4 7AL, UK j.muldoon@monash.edu 